\title{
A GERMAN “LINGUISTIC ISLAND” OR A LINGUISTICALLY MIXED REGION? MULTILINGUAL PRACTICES IN THE KOČEVSKA (GOTTSCHEE) AREA
}

ANJA MORIC

The article calls into question the understanding of the Kočevska (Gottschee) area as a "German language island". Through examples of the use of different languages before the Second World War, it shows a different-multilingual or multicultural-image of this region. The author draws data from historical and archival sources, as well as from a survey that she conducted among Gottscheers ("Gottschee Germans") living in Slovenia, Austria, Germany, the USA and Canada. Keywords: Gottschee, Gottscheers, Gottschee Germans, multilingualism, nationalism, linguistically mixed regions, linguistic islands, national identity
V prispevku so predstavljeni pomisleki o razumevanju območja Kočevske kot "nemškega jezikovnega otoka". Vendar primeri rabe različnih jezikov pred 2. svetovno vojno pokažejo drugačno - večjezikovno oz. večkulturno podobo te pokrajine. Avtorica podatke crpa iz zgodovinskih in arhivskih virov ter iz raziskave, ki jo je opravila med Kočevarji (kočevskimi Nemci) v Sloveniji, Avstriji, Nemčiji, ZDA in Kanadi.

Ključne besede: Kočevska, Kočevarji, kočevski Nemci, večjezikovnost, nacionalizem, večjezična območja, jezikovni otoki, narodna identiteta

\section{INTRODUCTION}

This article focuses on the Kočevska (i.e. Gottschee) region in southeastern Slovenia, known as the former "German linguistic island". The mentioned concept that implies its Germanness, was attributed to Kočevska in the $19^{\text {th }}$ century, and though there are several witnesses to the actual multilingualism of this area, it persists to this day. The first traces of settlement in Kočevska date back to prehistoric times (cf. Mantuani, 1924-1925; Simonič, 1939: 45; Jamnik, Velušček, 2011); however, the forest areas were mostly cleared and settled only at the time of medieval colonisation. Several theories exist about the origin of the Gottscheers. The findings of Austrian linguists, based on the analysis of the Gottscheer dialect, are the most widely accepted. According to these, most immigrants from northern estates in Carinthia and Tyrol -the Puster and Lesach Valleys- were settled in the Kočevska area by the Counts of Ortenburg in the 1330s (Petschauer, 1984: 87). On the other hand, according to the writing of the Bishop of Ljubljana, Tomaž Hren (consecrated in 1599), 300 rebellious families from Franconia and Thuringia were also sent to the Kočevska region after the end of the first phase of colonisation (Grothe, 1931: 33). Some of the immigrants are even said to have come from other Slovene-speaking areas - Stari Trg pri Ložu, Lož, Cerknica, and Idrija (Petschauer, 1984: 87-88), but a small number of Carinthian Slovenes were probably also among them (Simonič, 1971: 9). Due to immigration from diverse locales where different languages and dialects were 
spoken, as well as due to contacts with the surrounding population, an interesting mixed linguistic area developed in the Kočevska region, where for 600 years - until the resettlement of most of the population to the German Reich in 1941/42-, the Gottscheebarisch or medieval German with admixtures of Slovene (Schröer, 1869; Hauffen, 1895; Tschinkel, 2004 , etc.) was used predominantly. Nationalist ideas, including the notion of "German linguistic islands" that spread across Europe in the nineteenth and twentieth centuries, were not open to diversity as could be found in the Kočevska region (Moric, 2020) as well as in other mixed regions of Austro-Hungarian Monarchy (Judson, 2006; Zahra, 2008), since they did not focus on similarities and coexistence but on differences and borders (cf. Barth, 1998) demarcating ethnic groups. Relations between "Germans" and "Slovenes" from the Kočevska area radicalised increasingly at the turn of the nineteenth and twentieth centuries, and ethnic divisions became even stronger after the end of the First World War or after the establishment of new state borders (Moric, 2021). During the Second World War, which fatally shaped relations in the Kočevska region, Gottschee Germans opted to resettle near Brežice, on the then-border of the German Reich, on the basis of the agreement between Hitler and Mussolini. After the war they found homes in Austria, Germany, the USA and Canada, where active emigrant communities can be found today. In the article I address the aforementioned concept of the "German linguistic island" and the unambiguous understanding of the pre-war reality in the Kočevska region. In addition, I present some examples from which it is evident that the area was not monolingual or mononational, but rather multilingual and multilayered. In doing so, I refer to various historical sources, and above all to the data I collected in the qualitative part of the research The Maintenance of the Gottscheer Identity (MGI), i.e. while conducting my field work among Gottscheers in Slovenia, Austria, Germany, the USA and Canada during the years 2007-2015.

\section{PERCEPTION OF THE “GERMAN LINGUISTIC ISLAND”}

As in other parts of Europe (Anderson, 2007; Hobsbawm, 2007, etc.), the $19^{\text {th }}$ century brought national differentiation to the Kočevska region. This was particularly encouraged by the arrival of foreign, German-speaking intellectuals and bureaucrats inspired by romantic-nationalism, who searched the Kočevska area for supposed ancient elements of Germanness. The ethnography of the linguistic islands or Sprachinselvolkskunde that began in the 1930s (Heinke, 2015), pushed the multiculturalism or multilingualism of Kočevska into oblivion and began to emphasise its Germanness. "Islands" located outside the homogenous German-speaking area, in addition to Kočevska region also including e.g. Szepes, Brno, and Jihlava, were because of their remoteness considered linguistic and

\footnotetext{
1 See Moric, 2018a: 9, for more information on the research The Maintenance of the Gottscheer Identity.
} 
cultural relics (Heinke, 2015) where German researchers began searching for elements of the "ancient German soul". As the very appellation of the "linguistic island" suggests, language, as well as dialects, was at the centre of research, and this also included folk tales and folk songs. Subsequent research also included historical and cultural features. By emphasising the peculiarities of the "linguistic islands", they influenced the process of differentiation between Germans and Slovenes in the Kočevska region.

One of the first to become interested in the Gottscheer people was Jožef Rudež, a nobleman from Ribnica, who in 1823 wrote down examples of the Gottscheer dialect and the texts of four Gottscheer folk songs. His publication in the Vorzeit und Gegegnwart periodical was followed by other collectors of national treasures, among them Emil Korytko, whose premature death prevented him from publishing a monograph with the collected Gottscheer folklore materials. The Gottscheer culture, the past and customs then quickly became the subject of academic interest - particularly by intellectuals from Germanspeaking countries who came to Kočevska with the aim of conducting research, or who were employed there as teachers and officials. As the author of the first dictionary of the Gottscheer dialect, Karl Julius Schröer, wrote in 1891, the Gottscheer "Germanic people [...] have in fact preserved the best features of the German essence and are especially appealing due to the ancient features that have been perpetuated in isolation. That is, their language, their habits and customs, especially fairy tales and songs that express the deep and sincere soul of the people" (Schröer, 1891: 418). The collection of folk tradition, including folk songs, together with the establishment of German schools in bilingual villages, supported by the German nationalist organisation Deutscher Schulverein and other nationalist activities, became the basis for emerging nationalism in Kočevska. These tendencies still intensified after the First World War, which brought about new political circumstances and change to the status of the Gottscheers that became a minority in the newly formed Yugoslav state. Interest in the German "linguistic islands" which at the time remained stranded in the middle of the "threatening Slavic sea" thus increased.

The perception of a closed-off "German linguistic island" in the Kočevska region is still present today, and practically is not brought into question. This is inappropriate at least for linguistic reasons, since the inhabitants of the areas that are today most often identified under notions such as "German linguistic islands" (in our case Gottscheers) were mostly (at least) bilingual, even though nationalists on both sides, German and Slovene, liked to lay claim on them. For these, as suggested by Pieter Judson (2008), it is more correct to use the term "linguistically mixed areas", which implies use of several languages and coexistence between their speakers, a practical reality of these areas until the emergence of nationalisms in the $19^{\text {th }}$ century or the change of political borders after the First World War. Such an appellation transcends nationalist divisions that are still (though perhaps unconsciously) present in scientific research today (Weber-Kellermann, 1959). 


\section{THE BEGINNINGS OF NATIONAL DIFFERENTIATION (IN THE KOČEVSKA REGION)}

The events in the Kočevska region in the $19^{\text {th }}$ century can only be understood when placed in a broader historical picture of events in the then Austro-Hungarian Monarchy. The historian Judson has dealt with the emergence and rise of nationalism in three linguistically mixed areas of the Austrian part of the former Austro-Hungarian Empire: the Czech Republic, South Tyrol and South Styria. He pointed out that until the rise of nationalism in the second half of the $19^{\text {th }}$ century, there were no (significant) tensions or divisions among the local population based on linguistic diversity, as they easily used several languages and did not identify their ethnicity according to language (Judson, 2006: 3). Similarly, Vasilij Melik (1992: 171) describes the linguistic situation in the territory of present-day Slovenia. He notes that at the beginning of the $19^{\text {th }}$ century the peasant population spoke predominantly Slovene, while the population in the larger towns was bilingual and spoke both German and Slovene. The upper class and part of the bourgeoisie generally communicated in German, regardless of their mother tongue or origin. However, the use of language at that time did not yet determine the (national) affiliation of the population. Until the emergence of nationalisms (throughout Europe) with the March Revolution of 1848 , the identity of the population in the area of present-day Slovenia was mainly local and regional (Drnovšek, 2005; Čuček, Cvirn, 2012: 30).

The transition from older forms of identification associated with the city and the countryside, towards identification with one's own linguistic and "national" group in the modern sense, received its first impetus only after the outbreak of the March Revolution in 1848. (Čuček, Cvirn, 2012: 30)

In some places in the multilingual areas of the Austro-Hungarian Monarchy, bilingualism was promoted as early as the $19^{\text {th }}$ century. In order for children to learn both regional languages, parents in rural areas of Moravia and the Czech Republic swapped children for longer periods of time, and in parts of Styria and Carinthia they traditionally requested establishment of bilingual schools (Judson, 2006: 3). Similarly, in the 1860s, some Gottscheer people from Planina, where the German school was located, preferred to send their children to a bilingual school in Črnomelj (Trdan, 1999: 62). An interesting example of unforced multilingualism can also be found in the record of Bishop Anton Bonaventura Jeglič, who on 18 October 1899 reported about the visit of villagers from the village of Zdihovo, where there were 52 German and 11 Slovene houses. Although the local parish priest Mausser also preached in Slovene language, Slovenes nevertheless preferred to visit sermons conducted in German language (Otrin, Čipić Rehar, 2015: 45). Such self-evident and unforced bilingualism, however, could by no means be accepted by nationalist ideologues. Multilingual areas have been defined as "border regions" where 
there has always been a conflict between speakers of different languages. In this way, local societies asserted differentiation or caused national polarisation among the population of these regions.

Mutual tolerance between different language communities was dismantled only by external nationalists from German and Austrian cities, who through the establishment of German schools, tourism and newspapers created conflict between Germans and Slovenes (as well as between Germans and Czechs and other peoples of the monarchy) (Judson, 2006: 3). After the exclusion of Austria from the German Confederation in 1866, the Germans became a minority in the monarchy but made great efforts to maintain a leading role in the cultural, political, and economic fields (Promitzer, 2004: 188). After the defeat of the German Liberal parties in the parliamentary elections of 1880 and the defeats in the elections to the provincial assemblies, they were faced with the fact that there were fewer German-speaking inhabitants in the monarchy than they had imagined, and with the fact of the legitimacy of the demands of Slavic nationalists for the use of their languages in the offices (Judson, 2006: 16). In order to defend Germanness and the German language from foreigners -Slavs and Italians (Drobesch, 1992: 190) - intellectuals (teachers, doctors, etc.) began to move to rural parts of Austria, which were also visited by nationally inspired tourists. They were perceived as the carriers of social change or as bearers of progress and greater national consciousness. In the early $20^{\text {th }}$ century, teachers played a leading role in promoting nationalist organizations. In the 1880 s, Czech, Slovenian, and German nationalists recruited itinerant teachers for their own purposes, who visited remote places where they encouraged nationalist cohesion (Judson, 2004: 142; 2006: 74-84; on Kočevska, see Rus, 1939: 143). The zealous national activists - professors from Austria- were brought to the Kočevska area by the Gymnasium (State Lower Grammar School) in Kočevje, founded in 1872. The most prominent among these were Benedict Knapp, Josef Obergfoll and Peter Wolsegger. Knapp in particular was a well-known nationalist who also brought a German kindergarten to Kočevje (Rus, 1930: 64). Obergfoll and Wolsegger, on the other hand, were particularly active in publishing numerous historical and ethnographic writings. Territorially and ethnically oriented forms of the nationalist ideology of German bourgeois political parties were implemented by two voluntary organizations that aimed to promote national consciousness among the German-speaking inhabitants of the empire and encourage the growth of the number of German-speaking people. In 1880, activists founded the Deutscher Schulverein (German School Association) in Vienna, which raised money for German schools in linguistically mixed areas (Judson, 2006: 17). The initiative to establish this organization came mainly from the Viennese centre, while the proponents from linguistically mixed regions only formed a minority (Drobesch, 1992: 188), which shows that the "conflict" was created outside the multilingual areas themselves. In 1885, they were followed by Slovene nationalists with the establishment of Družba sv. Cirila in Metoda (The Society of Sts. Cyril and Methodius) (they have already been preceded by the Czechs, Italians, and Poles with similar organizations). Another German nationalist 
organization, Südmark, bought land to support and expand Germanness in linguistically mixed regions, settled German colonists there, and also supported German schools and libraries (Otrin, Čipić Rehar, 2015: 171).

Practically the only difference between the inhabitants of linguistically mixed areas that nationalists could highlight was linguistic. Therefore, nationalist organizations strived to build national schools that would educate children to be loyal members of a particular nation (Judson, 2006: 21-22). The aforementioned Deutscher Schulverein was founded with the aim of developing a German educational system

in Austrian lands with ethnically mixed populations, on borders of Germanspeaking areas and German language islands [...] Before World War One, it raised around thirty million Austrian crowns for this purpose and built more than three hundred new schools and provided support and loans for the construction of more than 420 school or other facilities. Where it did not receive the necessary funds from the local authorities to build a new German school, or where there were no legal conditions for establishing a public German school because there were too few German children, it built the school with its own funds and maintained it as a private school. Until there were a sufficient number of German or Germanised children, and then, under certain conditions -among which the basic one was that the school had to be German-only- it was transformed into a public German school maintained by the authorities. Of course, the association tried to create conditions for a public German school as soon as possible by Germanising children, and also helped by establishing German kindergartens and special children's colonies, German libraries, etc. (Ferenc, 1968: 67-68)

The basis for such action was the Constitution of 1867, which guaranteed the peoples of the monarchy the right to education in their own language; the Imperial Elementary School Act of 1869 thus provided for the establishment of state minority schools in all areas where for five consecutive years, an average of 40 children lived at a distance of four kilometres or one hour's walk. The act also encouraged Slavic nationalists to demand the use of their own language in schools and offices where the Slavic population formed a majority (Judson, 2006: 24-27).

The Schulverein opened its branch in Kočevje as early as 1881 after the efforts of Benedict Knapp, and a year later founded a woodcraft school, which was soon nationalized although it lacked students (Rus, 1930: 65). Focus was in particular on the establishment of schools on the outskirts of the Kočevska area, which they perceived as being the most endangered. The first Schulverein German school in Kočevska was opened in 1882 in Mavrlen. However, the plan to nationalize it failed as it did not obtain the prescribed number of children despite much effort (ibid.). Where schools already existed (e. g. in Smuka and Kočevske Poljane), the Schulverein used a different tactic, namely it provided 
significant financial support under the condition that the language of instruction will be exclusively German (ibid.: 66). In 1914, Schulverein owned 8 schools and 4 kindergartens, and furthermore financially supported 11 schools and 2 kindergartens (Kordiš, Škufca, 1995: 13).

The most obvious struggle for the "creation" of Germans and Slovenes was expressed in the western part of Kočevska - in the Dragarska dolina (Dragarska Valley). The church conflict flared up in 1889/90, when German parishioners in Draga allegedly demanded that German sermons be introduced in worship, and the dispute had to be resolved by the Bishop of Ljubljana, Jakob Missia (Trdan, 1999: 71). Things became volatile again at the end of 1902, the reason why Missia's successor, Bishop Anton Bonaventura Jeglič, also travelled to Draga in December to observe in person the ethnic image of the place. The Kočevje District Governor Michael Gstettenhoffer, the Kočevje Mayor Alois Loy, gymnasium teacher Josef Obergföll who had moved from Tyrol, and Kočevje Gymnasium Headmaster Peter Wolsegger, also an immigrant from Tyrol, convinced him of the German character of Draga and the surrounding villages, which is why they wanted the religious instruction to be held in German. Jeglic found that the use of the Gottscheer dialect predominates in Draga and its surroundings, while all adults also spoke Slovene since a third of them immigrated from the surrounding Slovene villages (Otrin, Čipić Rehar, 2015: 181), and many also had contacts across the border in Croatia. Jeglič did not report on the use of High German in everyday life. He wrote:

The service of God has always been in Slovene here, as well as Christian teachings at school. Around the year 1835, when the parish was transferred from Trava to Draga, German was preached in Draga for some time, but because people knew only Slovene and Gottscheerisch and did not understand German, the faithful did not visit the service of God until the introduction of the Slovene language. [...] 1. if we look at the colloquial language, I would say that there are mostly Germans here, 2. if we look at the lineage, partly the current and partly that of the grandfathers, we must say that they are all Slovenes, but 3 . it is especially in the villages of Trava, Srednja Vas and Draga that they have an awareness that these are German villages, 4. people know Slovene and must also know it, because they only have Slovenes as their neighbours and are completely mixed with Slovenes, 5. they should also learn German well, 6. the church is absolutely right not to deviate from the Slovene language either in the church or in the school, which would only be to the detriment of the inhabitants, all the more so because 7 . there are German schools and parents are somehow forced to send their children to these schools. (Otrin, Čipić Rehar, 2015: 181-182)

It can be concluded that the parishioners did not have any problems with understanding Slovene, or that, on the contrary, they had difficulty understanding the standard German 
language. Therefore, it is likely that the dispute over the use of language in the church was created or at least inflamed primarily by (the above-mentioned and other) intellectuals. Already in the preceding year, Jeglič mentioned that people were "instigated" by the forester of Prince Auersperg (Otrin, Čipić Rehar, 2015: 116). The impact of Schulverein who had their branch in Trava near Draga before 1905 and also supported the schools in Trava and Draga (Trdan, 1999: 59) should not be neglected. The German school in Trava was founded in 1898 (Turk, 2007: 44) by Südmark and in 1902 it was even (temporarily?) achieved that the provincial council forbade the priest to hold religious instruction in Slovene. Even then, Bishop Jeglič opposed this because:

everywhere, only Slovene language was used for praying at home, because all the service of God is only held in Slovene, because most people are of Slovene descent and because the Gottscheer people here do not understand German, but if there exists a single schoolboy who only knows German, he should be taught in German. (Otrin, Čipić Rehar, 2015: 171)

In addition to the church, a school "war" took place in Draga or the so-called "Fight for Draga" as the events were vividly termed by the Slovenski narod (Slovenian Nation) newspaper (Beg, 1911: 13). In 1883, when the Utraquist school in Draga was abolished, the provincial school council ordered the division of pupils into Slovene and German classes according to their mother tongue, with compulsory instruction in another provincial language. Both classes, however, were taught in shifts by the same teacher. As long as Slovene teachers were supported by Družba sv. Cirila in Metoda (Society of Sts. Cyril and Methodius), the Slovenian class was more frequented than the German one (Beg, 1911: 12). When the latter withdrew its support, the teaching in both departments was taken over by the Gottscheer teacher Tscherne, who, with the support of the Schulverein and Auersperg's forest keeper Künzl, successfully campaigned for Germanness: "The inhabitants depend on the prince, or on his keeper for earnings, pastures, supply of firewood, etc. And Schulverein sends rich Christmas presents, which deceives the parents and children" (Beg, 1911: 12).

The Schulverein or German nationalists wanted to attract not only German-speaking children to German schools, but also children from the so-called mixed marriages and also from entirely Slavic families, by providing better equipment, material benefits in their schools, e. g. free books or better Christmas presents (Judson, 2006: 44), the same tactics were used by Slovenian nationalists. In his memoirs, the teacher of Družba sv. Cirila in Metoda Andoljšek described the situation in Draga as follows:

I never forget what conflict arose in front of the school when I asked the parents in which class I should enrol the children. The misled Slovenes thought that all the children would be taught in the German class. But the nationally conscious 
men held on. Both classes were somehow equally strong. And what was the consequence of this unnatural division? The school in Draga has become a unique example, perhaps in the whole of the world, and to the ridicule of pedagogy. [...] And now lessons in the German class. Poor children! I started in German; no one understood me; I did not know Gottscheerisch. The misled persons demanded that I have to get used to the Gottscheer dialect. Prince Auersperg's servants spied everywhere; the gendarmes were always on my heels and denounced every word I uttered in Kočevje. (Andoljšek, 1930: 57)

From 1890 until his departure for Slovene supremacy in the Dragarska dolina, Andoljšek strived with the means at his disposal: he often organised national festivities for Družba sv. Cirila in Metoda, banned German prayer books and distributed Slovene ones published by the same society (Andoljšek, 1930: 58-59). Society of Sts. Cyril and Methodius established some of its branches in the Kočevska region: in 1886 in Trava and Draga, and for Kočevje and its surroundings in 1910 (Ferenc, 2005: 56), but it did not persist in the places it considered to be lost.

National divisions were also incited by censuses, which forced the population of linguistically mixed areas to choose only one language from the 1870 s onwards. In the first official census of 1880, people were asked about their colloquial language, not their nationality or mother tongue, and respondents could only list one language, whereby the fact of bilingualism (in some areas) had been ignored. The official census became a tool for proving which nationality or language predominates in which area (Judson, 2006: 14-27). The census was the basis on which German nationalists -statisticians, geographers, ethnographers, and historians- built the image of German superiority (cf. Promitzer, 2004). The figures were also important to Slovene nationalists, who also constantly checked the number of Slovenes and strove to increase it (e.g. Beg, 1911). The politicisation of censuses was also shown in the case of Draga, where in 1880, 78 people identified themselves as Germans and 158 as Slovenes. Only a decade later, in 1890, the situation was completely reversed, i.e. with 238 Germans and 20 Slovenes in the village (Grothe, 1931: 96).

\section{WITNESSES OF FORGOTTEN MULTILINGUALISM IN KOČEVSKA}

Due to the decreasing number of Gottscheers, direct information about life in the Kočevska region before the Second World War is becoming increasingly difficult to access. Records of multilingualism and coexistence among speakers of different languages are found mainly in archival sources such as school reports, newspapers, church books, and literature. For example, Tomšič and Ivanc, who visited the town of Kočevje in 1887, reported as follows: "The vast majority of citizens are Germans, but you can speak Slovene in almost all shops and inns. The gymnasium has poor attendance; one third of the students are 
Slovenes and Croats" (Tomšič, Ivanc, 1887: 70). In the continuation of the article I focus particularly on the oral testimonies I collected during the research work conducted among the Gottscheers in Slovenia, Austria, Germany, the USA and Canada, where I managed to get direct information about relations between Slovenes and Germans and the use of different languages in the Kočevska area before the Second World War. Almost all of my interlocutors remember good neighbourly relations, whereby it is worth noting that relations at the micro-level (village) may have differed from those at the macro-level (state, politics), which was also found by Thomason (2010: 52). The intensity of contacts between "Germans" and "Slovenes" in the Kočevska region most likely varied according to the individual area. Particularly on the borders of the Gottscheer settlement area, there were closer contacts between the two communities, which is evident, among other things, from the emergence of mixed marriages. For example, Jože, born in Bistrica above Črnomelj, said the following to me: "Girls from the valley liked to come up because the Gottscheer lads were handsome. And the Gottscheer girls liked to go to the valley because life was easier there" (Jože, first generation, MGI).

The predominant language in the Kočevska region before the Second World War was Gottscheer dialect Gottscheerisch or Göttscheabarisch ${ }^{2}$, which was used throughout the countryside. The inhabitants of the town of Kočevje mostly spoke High German, which, as in other larger towns (Ptuj, Celje, Maribor), was an expression of the bourgeoisie. Brigitte (Graz, MGI) lived in Kočevje from birth until 1941. She said: "In the town of Kočevje, we didn't speak Gottscheerisch but German (hochdeutsch). I understand Gottscheerisch very well, but I don't speak it well."

Despite the similarity between Gottscheerisch and German, we can see from Bishop Jegličs journal entry and the testimony of teacher Andoljšek (see the previous section) that the inhabitants of Draga and the surrounding area who spoke Gottscheer dialect did not necessarily understand German. They were more familiar with Slovene which was spoken in the area. Fourteen years later, on 16 April 1917, at the other end of the Kočevska area, in Planina pri Črnomlju, where the school classes were held in the German language, the parish priest Viktor Kragl wrote in a visitation report:

2 Göttscheabarisch in the area of Kočevska in Slovenia is included in the group of "critically endangered languages" in the UNESCO Atlas of Endangered Languages of the World (Mosley, 2010), which means that it is known only to great-grandparents and is no longer used in everyday life (UNESCO Ad Hoc Expert Group on Endangered Languages 2003: 8-10). During the MGI survey, I found that the placement of Göttscheabarisch in the group of "critically endangered languages" does apply to the territory of Slovenia, while the dialect in the USA and Canada could be classified under the category of "highly endangered" languages, which include the languages/dialects spoken only by the generation of grandparents and the older generation, while the generation of parents understands the dialect but does not speak it with the children, therefore the use of the dialect is limited to formal occasions and events where older members of the community meet. I have extensively discussed the topic of preservation of the Gottscheer dialect in Moric, 2010, 2011. 
When a child comes to school, utmost care is taken to nurture the child's educational side. However, it is very difficult for beginners because they do not yet know the German language and so the child does not comprehend anything in the beginning, much less can he speak because he only knows Gottscheerisch. (Ljubljana Archiepiscopal Archive)

Similarly, several decades after the war, when the Gottscheers in Klagenfurt were visited by the countrymen from the Društvo Kočevarjev - staroselcev (Society of Native Gottschee Settlers) from Občice Slovenia, noted teacher Ludwig Kren, born in 1921 in Stara Cerkev, who now lives in Klagenfurt/Celovec:

At that time, it turned out that people spoke an even older way of Gottscheerisch, which has been preserved in the Črmosnjice valley. And it was also realised that these people are not able to speak German - a written language because they have never learned it. (Kren, first generation, MGI)

Therefore, the villagers of Kočevska area learned the German language only in German schools or German classes - before many were abolished by the Yugoslav authorities in the second half of the $1930 \mathrm{~s}^{3}$. This information alone could be enough to turn the perception of Kočevska region as an (exclusively) German (or German-speaking) enclave.

Language differences did not cause major communication difficulties. Slovenes who lived among the Gottscheers knew how to speak the Gottscheer dialect, while Gottscheers who lived in predominantly Slovene villages spoke (at least basic) Slovene. One of the interlocutors originating from the village of Dolnja Briga said the following:

We had good neighbours who were from Croatia. Their sons spoke Göttscheerisch, and with their parents we spoke Slovene. [...] Some parents also spoke a little Göttscheerisch. Like our neighbour who only knew a few words but understood us. My mother did not speak Slovenian, but they still understood each other. These were really good people. There was no hatred at the time and it didn't matter who you were or where you came from. (female Gottscheer, first generation, MGI.)

Jožefa's mother was born into a Gottscheerisch-speaking family in Smuka. She married a Slovenian from the nearby village of Pleš. Jožefa remembers that her mother

knew Slovene well, very well, perhaps just not certain words. When she came to Pleš to join a Slovene family, she did not know how to ask where those forks for mixing žganci

3 For more information on the abolition of German schools and classes in the Kočevska region, cf. Ferenc, 2005: 78-86. 
[local mush dish] were. Father was mischievous, so she went to ask grandmother, the mother on the father's side. But he pulled a fast one on her and told her that it was called burkeljce [fire tongs]. So she went to grandmother and said: "Dear mother, where are those burkeljce for mixing žganci mush?" "Come on, he is pulling your leg again!" [laughs] There were very few words she didn't know, for objects and whatnot. Otherwise, she spoke beautiful Slovene, wrote Slovene and German. She was also praised by the Gottscheers for writing beautifully, they called it Kornschrift, Kornschrift! It's a sort of high handwriting. (Jožefa Škedelj, in Moric, 2018b)

Jožefa knew Gottscheerisch as a child, but over the years she forgot this dialect due to lack of use. She remembers the use of Slovene and Gottscheerisch in the village.

I knew a lot but I forgot. I forgot a lot, too. Yet I knew. We played with the kids and whatnot. Across from here there was also a Slovene family, and we also spoke a lot of Slovene, didn't we? But I knew certain things. When my mother sent me to the neighbours' shop to go and buy one, instead of a loaf they said cautle, and then I took the change and purchased one cautle. (Jožefa Škedelj, in Moric, 2018b)

In some cases they also encouraged the use of German instead of Gottscheerisch. During the interwar period, three Gottscheer families and ten Slovene families lived in Bistrica, where Jože spent his childhood. His father was a Gottscheer and his mother a Slovene:

\section{At home we spoke only Slovene. Even with my father. When we cut the vines he would say to me: "You know what, Gottscheerisch is minor, you better learn German." During work he always translated Gottscheerisch words into German. I spoke German more easily than Gottscheerisch. I knew both Gottscheerisch and German at the time, but over the years I forgot because of the lack of use. (Jože, first generation, MGI)}

Jože's example shows that during the interwar period, some Gottscheers in the old homeland were of the opinion that the use of the German language was more useful than the use of the Gottscheer dialect, so they began to abandon the dialect: "Allowing children to learn and speak the old language has often been seen as an obstacle on the way to becoming successful individuals in the outside world" (Hutter, 2003).

If the Austro-Hungarian schools in the Kočevska region were German or Utraquist schools, in the new Yugoslav state, Slovenian language prevailed in school education. It seems that at that time the previously self-evident (voluntary) multilingualism was replaced by a compulsory one, as the Gottscheers recall the change of the official or school language as the greatest historical trauma that has befallen their community (cf. also Thomason, 2010: 47). The knowledge of Slovene was promoted by the school system among the 
Gottscheers born between the wars. Justine from Kitchener in Canada, attended school in Črmošnjice for two years:

The first year was in German only, but the second one was half-and-half. And then when we settled in the Untersteiermark [Lower Styria], we had neighbours that were Slovenian and had children my age and I was fluent in Yugoslavian, in the Slovenian language. But then, as we moved on again, of course you forget that. But now when they talk, I can still understand the other word. (Justine Sigmund, in Moric, 2018b)

Justine, as well as most of my other interlocutors, stopped using the Slovene language after the resettlement. The same is true of Rudolph, who has not used Slovene since settling in the USA: "Even in Austria I still spoke it, but I came to the United States and I lost the Slovenian language" (Rudolph Kump, in Moric, 2018b).

The actual multiculturalism or multilingualism of pre-war Kočevska is also evidenced in Gottscheer folk songs. One, the "Drei Madchen" (Three Girls), has been preserved in a pure bilingual form where one line is sung in German and the other in Slovene. It was recorded by Adolf Hauffen in his collection of Gottscheer folk songs in 1895. At the turn of the century, bilingual folk songs were also present in other mixed linguistic areas in Slovenia (as well as in Austria), but most of them were lost due to the selectivity of recorders, who considered them foreign and excluded them from national collections of folk songs. The song Three Girls was present in practically the same form among Carinthian Slovenes (Logar 2020) and in other multilingual regions of AustriaHungary (Eckard 2020). It is possible that it was brought to the Kočevska region by Gottscheer peddlers or other immigrants. The similarity of Gottscheer and Slovene folk songs was already recognised by the first linguists and researchers of Gottscheer folk songs (e.g. Schröer, 1891; Hauffen, 1895; Tschinkel, 2004) Hans Tschinkel (cf. Kumer, 1987: 249); an extensive comparative study was written by Zmaga Kumer for the fourth volume of the Gottscheer Volkslieder collection. The publication of the book, which was to contain comments on Gottscheer folk songs and findings on the mutual influences of the Gottscheer and Slovene traditions (Kumer, 1987: 249), was planned in the 1980s, but unfortunately was never realised and Kumer's manuscript, meanwhile, was lost in the Deutsches Volksliedarchiv in Freiburg. In addition to Kumer, other researchers have written about the similarities between the two traditions (Marolt, 1939; Ruch, 1982; Holzapfel, 1999; Golež Kaučič, 2018, etc.), whether it is either a common substance or the use of Slovene words and phrases (e.g. Mare, boh pomagaj!, Sinek Marko etc.). The latter could be said to be a reflection of multilingualism, which is reflected even in the Gottscheer dialect itself or in the multitude of Slovene words it contains (cf., for example, Hauffen, 1895; Steska, 1896; Tschinkel, 1908; Koštial, 1939: 328-331) and as such testifies to the fluid neighbourly relations in the Kočevska region. 


\section{CONCLUSION}

Relations between Slovenes and Germans in the Kočevska (Gottschee) region were marked by the broader political situation in Central Europe at the turn of the $19^{\text {th }}$ and $20^{\text {th }}$ centuries. Although both German and Slovene nationalist activists framed the area as belonging to their national or language category, the everyday reality of its inhabitants was different. In this article, I have tried to shed light on the relations between the Gottscheer, German and Slovene languages in the Kočevska region during the period before the Second World War, which also reveal a view of the initial stages of national movements in the this area. Since in the Kočevska region, in addition to the listed languages, Croatian and Romani were also spoken, it would be interesting to study their use in the future as well. This is the only way to complete the insight into the past language image of Kočevska region. Despite the actual multilingualism, the Kočevska region is still perceived today as a former "German linguistic island". The term does not take into account the multicultural nature of the area but is a reflection of the nationalist assumptions (and/or ignorance) of the researchers who are still using it. Intentionally or unintentionally, its use continues to project a onedimensional and incomplete understanding of relations between Germans and Slovenes in the Kočevska region, therefore it would make sense to consider abandoning it - if not elsewhere, at least in scientific vocabulary.

\section{REFERENCES}

Anderson, Benedict. 2007 (1983). Zamišljene skupnosti: O izvoru in širjenju nacionalizma. Ljubljana: Studia Humanitatis.

Barth, Fredrik. 1998. Introduction. InEthnic Groups and Boundaries: The Social Organization of Culture Difference, ed. Fredrik Barth, 9-38. Illinois: Waveland Press.

Beg, Ante. 1911. Slovensko-nemška meja na Kočevskem / poročal na I. obrambnem tečaju meseca julija 1910 $v$ Ljubljani Ante Beg. Ljubljana: L. Schwentner.

Čuček, Filip, and Janez Cvirn. 2012. Introduction. In Nemci in Maribor: Stoletje preobratov 1846-1946, ed. Jerneja Ferlež, 30-32. Maribor: Umetniški kabinet Primož Pemzl.

Drnovšek, Marjan. 2005. Izseljevanje Kočevarjev v Združene države Amerike. Dve domovini 21: 7-34.

Drobesch, Werner. 1992. Deutscher Schulverein: Njegova ideologija, notranja struktura in delovanje $s$ posebnim ozirom na Slovenijo. Zgodovinski časopis 46 (2): 187-198.

Eckard, John. 2020. Dvojezične pesmi kot terensko raziskovanje. Unpublished lecture at the conference Večjezičnost $\mathrm{v}$ folklori / Multilinguality in Folklore. ZRC SAZU, Institute of Ethnomusicology, Ljubljana, 1-2 October 2020, Prešernova dvorana SAZU.

Ferenc, Mitja. 2005. Kočevska - pusta in prazna: Nemško jezikovno območje na Kočevskem po odselitvi Nemcev. Ljubljana: Modrijan.

Ferenc, Tone. 1968. Nacistična raznarodovalna politika v Sloveniji v letih 1941-1945. Maribor: Založba Obzorja. 
Golež Kaučič, Marjetka. 2018. Slovenska ljudska balada. Ljubljana: Založba ZRC, ZRC SAZU.

Grothe, Hugo. 1931. Die deutsche Sprachinsel Gottschee in Slowenien: Ein Beitrag zur Deutschtumskunde des europäischen Südostens. Münster: Aschendorffsche Verlagsbuchhandlung.

Hauffen, Adolf. 1895. Die Deutsche Sprachinsel Gottschee: Geschichte und Mundart, Lebensverhältnisse, Sitten und Gebraüche, Sagen, Märchen und Lieder. Graz: K.K. Universitäts-Buchdruckerei, Verlagsbuchhandlung "Styria".

Heinke, M. Kalinke. 2015. Sprachinselforschung. In Online-Lexikon zur Kultur und Geschichte der Deutschen im östlichen Europa. https://ome-lexikon.uni-oldenburg.de/p32772.

Hobsbawm, Eric J. 2007 (1991). Nacije in nacionalizem po letu 1780: Program, mit in resničnost. Ljubljana: ${ }^{*}$ cf.

Holzapfel, Otto. 1999. Anmerkungen zu den hochdeutsch überlieferten Volksballaden in der Sammlung aus der Gottschee. Traditiones 28 (2): 43-52.

Hutter, Martha. 2003. What to Do About Our Old Language. Winter Jahresbrief / Newsletter 2003, Gottscheer Relief Association. New York: Gottscheer Relief Association.

Jamnik, Pavel and Anton Velušček. 2011. Arheološka in paleontološka jamska najdišča s širšega območja ribniške in struške doline ter Kočevske. In Spaha, ed. Anton Velušček, 33-64. Ljubljana: ZRC, ZRC SAZU.

Judson, Pieter M. 2004. Nationalizing Rural Landscapes in Cisleithania, 1880-1914. In Creating the Other: Ethnic Conflict and Nationalism in Habsburg Central Europe: Austrian History, Culture, and Society 5, ed. Nancy M. Wingfield, 127-148. New York, Oxford: Berghahn Books.

Judson, Pieter M. 2006. Guardians of the Nation: Activists on the Language Frontiers of Imperial Austria. Cambridge: Harvard University Press.

Judson, Pieter M. 2008. When Is a Diaspora Not a Diaspora?: Rethinking Nation-Centered Narratives about Germans in Habsburg East Central Europe. In The Heimat Abroad: The Boundaries of Germanness, eds. Krista O’Donnell, Renate Bridenthal and Nancy Reagin, 219-247. USA: The University of Michigan Press.

Kordiš, Ivan and Irena Škufca. 1995. Šolstvo na Kočevskem nekoč in danes. Kočevje: Regional Museum of Kočevje.

Koštial, Ivan. 1939. O Kočevcih in kočevščini. In Kočevski zbornik: Razprave o Kočevski in njenih ljudeh, ed. Janko Mačkovšek, 321-334. Ljubljana: Družba sv. Cirila in Metoda.

Kumer, Zmaga. 1987. Lepa voda Ljubljančica. Traditiones 16: 247-254.

Ljubljana Archiepiscopal Archive. Viktor Kragelj’s report. NŠAL14, parish Planina by Črnomelj, 16.4. 1917.

Logar, Engelbert. 2020. "Ein Mäderl früh aufstanden - je zgodaj v cerkev šla”: Jezikovno mešane pesmi na avstrijskem Koroškem. Unpublished lecture at the conference Večjezičnost v folklori / Multilinguality in Folklore. ZRC SAZU, Institute of Ethnomusicology: Ljubljana, 1-2 October 2020.

Mantuani, Josip. 1924-1925. Prazgodovinska gomila na Kočevskem. Glasnik Muzejskega društva za Slovenijo: 9-16.

Marolt, France. 1939. Slovenske prvine v kočevski ljudski pesmi. In Kočevski zbornik: Razprave o Kočevski in njenih ljudeh, ed. Janko Mačkovšek, 175-320. Ljubljana: Družba sv. Cirila in Metoda.

Melik, Vasilij. 1992. Nemci in Slovenci (1815-1941). Zgodovinski časopis 46 (2): 171-174.

Moric, Anja. 2010. Ohranjanje kočevarščine, narečja kočevskih Nemcev, v Sloveniji, Avstriji, Nemčiji, Kanadi in ZDA. Razprave in gradivo 61: 92-119. 
Moric, Anja. 2011. The Maintenance of Gottscheerisch, the Dialect of Gottschee Germans in Slovenia, Austria, Germany, Canada and the USA. Europa ethnica: Nationalitätenfragen=questions ethniques $=$ problems of nationalities: 68 (1-2): 21-31.

Moric, Anja. 2018a. Territorial Identifications of the Gottschee Germans: Diaspora - Homeland Relation. Motus in verbo 7 (1): 7-21.

Moric, Anja. 2018b. Globoko v srcu jo čutimo = Deep in our hearts we feel it = Tief im Herzen füblen wir sie. Ethnographic film. Stara Cerkev: Zavod Putscherle.

Moric, Anja. 2020. Gottscheer Folk Song: From a Means of Fostering National Differentiation to a Memory Keeper in the Diaspora. Traditiones 49 (2): 141-166. DOI: https://doi.org/10.3986/ Traditio2020490208.

Moric, Anja. 2021. Spomeniki padlim v prvi svetovni vojni na Kočevskem v luči povojnih razmer. In Dediščina prve svetovne vojne: Reprezentacije in reinterpretacije, eds. Jurij Fikfak and Božidar Jezernik, 87-114. Ljubljana: Znanstvena založba Filozofske fakultete. DOI: https://doi.org/10.4312/9789610604143-5888-1.

Mosley, Christopher, ed. 2010. Atlas of the World's Languages in Danger. 3rd Ed. Paris: UNESCO Publishing. http://www.unesco.org/languages-atlas/.

Otrin, Blaž, and Marija Čipić Rehar. 2015. Jegličev dnevnik: Znanstvenokritična izdaja. Celje: Celjska Mohorjeva družba.

Petschauer, Erich. 1984. »Das Jahrhundertbuch «: Gottschee and its People Through the Centuries. New York: Gottscheer Relief Association.

Promitzer, Christian. 2004. The South Slavs in the Austrian Imagination. In Creating the other: Ethnic Conflict and Nationalism in Habsburg Central Europe: Austrian History, Culture, and Society 5, ed. Nancy M. Wingfield, 183-215. New York, Oxford: Berghahn Books.

Ruch, Martin. 1982. Die Gottschee als Volksliedlandschaft. Jahrbuch Für Volksliedforschung 27-28: 175-185. DOI: https://doi.org/10.2307/848492.

Rus, Josip. 1930. Nemški Schulverein in Slovenci na Kočevskem. Koledar Šolske družbe sv. Cirila in Metoda 27: $62-73$.

Rus, Jože. 1939. Jedro kočevskega vprašanja: zgodovina, sedanjost in bodočnost kočevskega gospodarstva in njegovih prirodnih in socialnih podlag. In Kočevski zbornik: Razprave o Kočevski in njenih ljudeh, ed. Janko Mačkovšek, 131-173. Ljubljana: Družba sv. Cirila in Metoda.

Simonič, Ivan. 1939. Zgodovina kočevskega ozemlja. In Kočevski zbornik: Razprave o Kočevski in njenih ljudeh, ed. Janko Mačkovšek, 45-130. Ljubljana: Družba sv. Cirila in Metoda.

Simonič, Ivan. 1971. Zgodovina mesta Kočevja in Kočevske. In 500 let mesta Kočevje, eds. Herman Kotar, Marija Andeselič, and Miha Briški, 5-51. Kočevje: Skup̌̌čina občine Kočevje.

Schröer, Karl Julius. 1869. Ein Ausflug nach Gottschee: Beitrag der Erforschung der Gottscheer Mundart. Wien: K. K. Hof., Staatsdrückerei.

Schröer, Karl Julius. Gottschee und die Gottscheer. In Die österreichisch-ungarische Monarchie in Wort und Bild: Kärnten und Krain. [Bd. 8]. Erstes Heft, 417-429. Wien: k.k. Hof- und Staatsdruckerei, Alfred von Hölder.

Thomason, Bobbi. 2010. Memories of Gottsche: A Narrated History of Fidelity and Fragility. CreateSpace Independent Publishing Platform.

Tomšič, Štefan, and Fran Ivanc. 1887. Kočevsko okrajno glavarstvo: Zemljepisno-zgodovinski opis. Kočevje: okrajna učiteljska knjižnica, Ljubljana: Narodna tiskarna.

Trdan, Vanda. 1999. Življenje kočevskih Nemcev med 1850 in 1918. Master's Thesis. Ljubljana: University of Ljubljana, Faculty of Arts. 
Tschinkel, Hans. 1908. Grammatik der Gottscheer Mundart. Halle: M. Niemeyer.

Tschinkel, Wilhelm. 2004. Kočevarska folklora v šegah, navadah, pravljicah, povedkah, legendah in drugih folklornih izročilih. Ljubljana: Založba ZRC, ZRC SAZU.

Turk, Prvenka. 2007. Šole Dragarske doline: Boj proti nemštvu za slovensko šolo v Dragi. Šolska kronika $16=40(1): 44-66$.

UNESCO Ad Hoc Expert Group on Endangered Languages. 2003. Language Vitality and Endangerment. Document submitted to the International Expert Meeting on UNESCO Programme Safeguarding of Endangered Languages. http://www.unesco.org/new/fileadmin /MULTIMEDIA/HQ/CLT/ pdf/Language_vitality_and_endangerment_EN.pdf.

Weber-Kellermann, Ingeborg. 1959.Zur Frage der interethnischen Beziehungen in der "Sprachinselvolkskunde." Österreichische Zeitschrift für Volkskunde 13 (62): 19-47.

Zahra, Tara. 2008. Kidnapped Souls: National Indifference and the Battle for Children in the Bohemian Lands, 1900-1948. Ithaca: Cornell University Press.

\section{"NEMŠKI JEZIKOVNI OTOK"ALI MEŠANO JEZIKOVNO OBMOČJE?: VEČJEZIKOVNE PRAKSE NA KOČEVSKEM}

Na Kočevskem, vjugovzhodni Sloveniji, je 600 let-od 14. stoletja do 1941, ko je bila na podlagi dogovora med nacistično Nemčijo in fašistično Italijo večina prebivalstva premeščena v nemški rajh - obstajalo zanimivo mešano jezikovno območje. Glavni jezik in posebnost tega območja je bilo kočevarsko narečje, t. i. kočevarščina, ki je ohranila značilnosti srednjeveške nemščine in ponotranjila nekatere elemente slovenskega jezika. Čeprav so na Kočevskem poleg kočevarščine govorili tudi nemški, slovenski in celo hrvaški ter romski jezik, je to območje še danes dojeto kot nekdanji "nemški jezikovni otok«. Ker izraz "jezikovni otok"ne upošteva dejanske večjezične in večkulturne narave območja, hkrati pa odseva nacionalistične predpostavke avtorjev, ki ga uporabljajo, ga je treba ponovno premisliti.

Prispeveks primeri jezikovnih praks na Kočevskem pred 2. svetovno vojno pokaže dozdaj zapostavljeno večjezikovno podobo t. i. nemškega jezikovnega otoka na Kočevskem. Zgodnjo fazo nacionalnega gibanja oz. začetka delitev na "Nemce" in "Slovence " na Kočevskem postavi $v$ širši zgodovinski kontekst - v čas, ko so tudi v drugih večjezičnih pokrajinah avstro-ogrske monarhije potekale bitke za prevlado narodnih jezikov v javnem življenju. S predstavitvijo podatkov iz zgodovinskih in arhivskih virov avtorica problematizira enoznačno razumevanje razmerij med govorci različnih jezikov, ki so jih določale zlasti od zgoraj vcepljene nacionalne ideje nacionalisticnih aktivistov in njihovih organizacij ter jih utrdile spremembe politicnih mej. Predstavljeni so primeri večjezičnosti v različnih kočevskih krajih na prelomu iz 19. v 20. stoletje. Večjezikovna in večkulturna prepletanja na Kočevskem pred 2. svetovno vojno 
pa ponazarjajo tudi izsledki raziskave, ki jo je avtorica opravila med Kočevarji v Sloveniji, Avstriji, Nemčiji, ZDA in Kanadi.

Dr. Anja Moric, Assist. Prof., ZRC SAZU, Institute of Ethnomusicology; University of Ljubljana, Faculty of Arts, Department of Ethnology and Cultural Anthropology, anja.moric@zrc-sazu.si

The author acknowledges the projects (Thinking Folklore: Approaching Dialect from Folkoristic, Ethnological, and Computational Perspectives (J7-9426), Song Reflections on Intercultural Coexistence (J6-9369), A reflection of (former) multiculturalism and coexistence in the folklore and heritage practices of Slovene and Gottscheer immigrant communities in the United States of America (BI-US/19-21-012)) and the research core funding (Slovene Identities in the Context of the European Space, No. P6-0187) were financially supported by the Slovenian Research Agency. 